\title{
Entrepreneur's perceived risk and risk-taking behavior in the small-sized creative businesses of tourism sector during COVID-19 pandemic
}

\author{
Iin Agustina ${ }^{1 *}$, Mohd Na'eim Bin Ajis ${ }^{2 *}$, Hafid Aditya Pradesa ${ }^{3 *}$ \\ ${ }^{1}$ School of Administrative Science Bandung, Bandung, Indonesia \\ ${ }^{2}$ College of Law, Government and International Studies, Universiti Utara Malaysia, \\ Changlun, Malaysia \\ ${ }^{3}$ Polytechnic of STIA LAN Bandung, Bandung, Indonesia \\ *Corresponding Author(s) Email: iin.agustina@stiabandung.ac.id, naeim@uum.edu.my, \\ hafid.aditya@poltek.stialanbandung.ac.id
}

\section{ABSTRACT}

The small-sized creative business in the tourism sector has been suffering risks of bankruptcy since the outbreak of coronavirus disease (COVID-19). Drawing on the basic theory of reasoned action, this study aims to investigate entrepreneur risk perceptions affect their risktaking behavior. This study only focuses on the determinants of risk-taking, with regards to the perspective from an entrepreneurial lens in perceiving business, product, and profit risk during the COVID-19 pandemic. A quantitative approach using a structured questionnaire survey was utilized to attain the study objective. The dataset consists of 177 valid responses by the owner of the small-sized creative business of Indonesia's tourism sector (mainly in handicraft and fashion categories). Correlation analysis and partial least square (PLS) modeling were employed to examine the causal relationship between constructs. Our empirical findings revealed that while entrepreneurs' perceived risk on business and product aspects was the most significant aspect that could affect their risk-taking behavior, entrepreneurs' perceived risk on profit aspects have an insignificant influence on their risk-taking behavior. It implies that the higher the level of business and product insecurity perceptions (as long as it can generate profitability and ensure business sustainability), the higher the level of risk-taking of entrepreneurs.

Keywords: COVID-19; Tourism; Perceived Risk; Risktaking; Entrepreneurship; SMEs
JEL Code:

L26, M13

DOI:

10.31106/jema.v18i2.12563

Article History:

Received 2021-08-04

Reviewed 2021-08-30

Revised 2021-09-09

Accepted 2021-10-10

Licensed:

CC-BY 
Entrepreneur's perceived risk and risk-taking behavior in the small-sized creative businesses of tourism sector during COVID-19 pandemic by lin Agustina,

Mohd Na'eim Bin Ajis, Hafid Aditya Pradesa

\section{Introduction}

Since early 2020, the rise of the pandemic outbreak has had a tremendous impact on whole countries. Pandemic situations have been recognized as unavoidable situations which affect many aspects of life. Lockdown, quarantine, and isolation as a result of the incessant escalation of the pandemic caused people to feel anxious, and consider themselves to be at risk of COVID-19 (Y1ldırım \& Güler, 2020). The deepening multiple pandemic effects in many countries has resulted in a general trend of increasingly restrictive policies toward many aspects of society (Agustin, 2021; Tahar et al., 2021). It brings an increasing understanding of risk, as evidenced by several recent studies reviewing the perceived risk of COVID-19 that is experienced by people in several regions of the world (Dryhurst et al., 2020; Huynh, 2020).

Entrepreneurship is identical to risk-taking behavior. For many entrepreneurs, risk-taking goes hand in hand with business growth. In some cases, risk-taking is often related to entrepreneurial motives (Nathasia \& Rodhiah, 2020; Wijaya et al., 2015). The entrepreneurs' behavior in taking a risk often refers to their perception of risk. Weber et al. (2002) strengthen the argument by stating that the perception of the risk posed by each risky behavior. Several studies have analyzed the relationship between perception and behavior which have shown that a risky behavior has the potency to encourage individuals involved in such behavior (Soane et al., 2010; Weber et al., 2002). This study uses the reasoned action theory, as an elaboration results of planned behavior theory, which argues that people's perceptions and/or attitudes towards certain behaviors drive their behavioral intentions and ultimately shape their behavior (Ajzen, 1991). It is crucial to understand the role of entrepreneur subjectivity in perceiving risk so that it can be future guidance to understand the reason behind their risk-taking or avoidance behavior (Dislich et al., 2010). The subjective perception and relative optimism of entrepreneurs are closely related to the basis of judgmental decision-making and entrepreneur characteristics (Cheung et al., 2013).

Risk perception and risk-taking have been developed as the basis of individual personality (Mishra et al., 2010; Soane et al., 2010). Thus, the level of exposure to knowledge involving risk will affect the appropriate risk estimation of an individual (Riddel, 2009). An individual can predict risk better by having more information. Some people who have more information tend to experience more ambiguity than people who have less knowledge of risk information. This is the way people construct their perceptions of risk and the possibility of 
different perceptions of risk. Even an individual in the same situation is likely to have different views about the sources of risk and how each source relates to the level of risk assessment (Joo et al., 2021). There are numerous previous studies investigated the impact of risk perception on risk-taking behavior across multiple individual levels and a variety of contexts (Bohm \& Harris, 2010; Cheung et al., 2013; Christman et al., 2007; Dionne et al., 2007; Kummeneje \& Rundmo, 2020; Laurence Kern et al., 2014; Reniers et al., 2016). For example, Reniers et al. (2016) investigated the relationship between these two variables by relating age and gender to determine personal characteristics, while some authors investigated risk scenarios from the perspective of (SMEs) experts and drivers (Bohm \& Harris, 2010), cyclists (Kummeneje \& Rundmo, 2020), and tourists (Chew \& Jahari, 2014; Floyd et al., 2004). Joo et al. (2021) have investigated risk perception from a resident's perspective, emphasizing that tourism research to date has failed to acknowledge the importance of perceived risk in the interaction between tourists and tourism as a whole. In the current study, a researcher has endeavored to fill a gap in the literature on risk perception and acknowledges its effect on risk-taking. A large body of previous research has shown that risk perception is considered a subjective psychological construct that is influenced by emotional, cognitive, and social (Kasperson et al., 1988; Loewenstein et al., 2001; Slovic et al., 2004; Slovic \& Peters, 2006). However, there hasn't even been a previous study exploring this relationship directly in the context of entrepreneurship and crises.

This study, undertaken from the entrepreneurs' perspective, is addressed to provide empirical evidence on how entrepreneurs from popular tourism cities in Indonesia perceived risk during the COVID-19 pandemic. The situational context of the pandemic could provide value-added to empirically explore phenomena in the field regarding risk perception and risktaking. By framing the concepts in the two theoretical frameworks, focusing on both theory of reasoned action and theory of entrepreneurship, it is believed that risk-taking for entrepreneurs during this pandemic could be influenced by the extended risk perceived by entrepreneurs.

\section{Literature Review}

\section{COVID-19, Tourism, and Entrepreneurship}

Studies related to the tourism crisis have been a hotly debated topic since the COVID-19 pandemic. This is because the tourism sector is seen to be highly affected as a result of this pandemic which has never been faced by this sector before (Zhao \& Xu, 2020). History has also shown that the threat of disease has a link to long-term and short-term crises in the 
Entrepreneur's perceived risk and risk-taking behavior in the small-sized creative businesses of tourism sector during COVID-19 pandemic by lin Agustina,

Mohd Na'eim Bin Ajis, Hafid Aditya Pradesa

tourism and hospitality sectors. In 2003, the SARS epidemic had hit China and it greatly affected the tourism sector in China (Karim et al., 2020). Meanwhile, in 2014-2015, the Ebola virus outbreak has hit African countries, especially Guinea, Liberia, and Sierra Leone. It has caused these countries to experience severe economic downturns including the tourism sector. In Sierra Leone, due to the Ebola virus, all flights have been canceled (Kongoley, 2015).

Thus, many stakeholders in the tourism and hospitality sector used sustainable strategies in reducing the impact of this COVID-19 pandemic (Le \& Phi, 2021). This action is important because it can maintain business viability for hotel owners, travel agencies, and other business actors (handicrafts, fashion, food, and beverages), especially in the tourism sector. For example, in the hotel industry, several hotel operators have implemented two forms of strategy: service transformation and hibernation. In the aspect of service transformation, the hotel has collaborated with government agencies in providing accommodation services when the government introduced 14 days of quarantine to certain parties such as quarantine for people who have just returned or arrived from abroad. Meanwhile, the hibernation strategy used by the hotel is to reduce operational costs such as offering early termination, temporary cessation of operations, etc. (Davidson \& Wang, 2011).

On the other hand, forming a strategy for small business owners (SMEs) is more difficult due to limited resources and unstable supply chains. Therefore, this pandemic has made SMEs experienced a significant decline since it depends on tourism activities. SMEs are known to be much more vulnerable (more fragile) during a crisis than large companies (Bartz \& Winkler, 2016). Therefore, they are not ready to carry out business sustainability. As mentioned by Kato \& Charoenrat (2018) that amid the current pandemic, many SMEs have stopped operating because most of them do not have experience in preparing for business sustainability, including building organizational resilience during the crisis.

Most of the parties in the tourism and hospitality sector affected by the COVID-19 pandemic have implemented various sustainable strategies to keep their businesses sustainable and to avoid the increasing number of unemployed people. However, the termination of employment, payroll deductions, and unpaid leave are unavoidable by most employers in both sectors because the impact of this pandemic is extremely large, unprecedented, and takes a very long time to recover. The COVID-19 pandemic had led to a significant step in rethinking the global volume model for tourism (Gössling et al., 2020), to the interrelated risks posed in global travel. While previous studies have highlighted the 
dynamic impact of the pandemic on the tourism sector and its recovery (Lapointe, 2020; Nepal, 2020; Sigala, 2020), everyone is aware that this crisis has brought so many changes in every area of life, and entrepreneurship is no exception (Liñán \& Jaén, 2020; Ratten, 2020b, 2020a). Therefore, one should expect a dramatic reduction under this perspective, especially in the number of entrepreneurial projects undertaken in some tourism areas.

\section{Perceived Risk}

Actions and understandings of risk, similar to any other experiential phenomenon, are informed by culturally and socially structured conceptions and evaluations of the circumstances in this world, what it is like, what it should or should not be (Boholm, 1998). The task of defining risk has long been fraught with controversy and confusion, Current studies in psychology and management generally define risk as a condition in which the consequences of a decision and the probabilities associated with those consequences are known as entity or "measured uncertainty" (Wolff et al., 2019). In economics and psychology, based on expected utility theory defines risk as to the result of people's assessment of the probability and severity of negative outcomes.

On the other side, Jungermann \& Slovic (1993) argued that the term perception is more widely used in cognitive psychology which applied to a person's mental processes through the way they receive, handle, and assess information from the environment (both physical and communicative) through the senses. The perception of risk is well investigated in the previous scientific literature (Slovic, 1987, 1992), especially about various factors related to an individual's risk perception (Renn et al., 1992). However, this study mainly focuses on the characteristics of risk perception in entrepreneurship, which are determined by individual differences, context, the way risk is processed, and how information is communicated.

Risk perception is recognized as being related to a person's cognition and affection (Arini, 2016; Slovic et al., 2005; Slovic \& Peters, 2006), and several researchers review risk as a form of feeling (Loewenstein et al., 2001; Slovic et al., 2004). From the first time this concept was introduced, researchers have confirmed the role of context and perspective in the use of this very broad and interdisciplinary nature of risk perception. The evidence to date suggests that common people's risk perceptions could be modeled with relatively simple structures (Holtgrave \& Weber, 1993; Slovic, 1992). This conceptualization of risk perception recognizes the multifaceted nature of perception under conditions of risk.

The study of risk perception has focused on a long list of problems related to risk. Another attempt to study risk perception across national lines draws attention to one issue. 
Entrepreneur's perceived risk and risk-taking behavior in the small-sized creative businesses of tourism sector during COVID-19 pandemic by lin Agustina,

Mohd Na'eim Bin Ajis, Hafid Aditya Pradesa

While measuring concerns about various hazards is useful, hazards that are evaluated as risky can cause worry and anxiety, they don't necessarily have to be. The question of risk is central to life both in society and individually, with humans living in a universe of meaning, not in a world governed by statistics (Le Breton, 2018).

Based on those descriptions, the simple meaning of the concept is the subjective probability held by an individual for a certain event. In this study, risk perception will be measured through questions for entrepreneurs about the magnitude of damage from pandemic effect and probability of the damage occurrences in three aspects of risk perception were measured. As risk perception is known as a multifaceted construct, it is believed that the important aspects related to the perception of risk in business caused by the pandemic situation are about (1) business, (2) profit, and (3) product.

\section{Risk-Taking Behavior}

In the classical decision theory, the risk is often understood as reflecting variations in the distribution of possible outcomes, their probability, and their subjective value (March \& Shapira, 1987). The idea of risk is embedded in decision-making is attested by its position in decision theory. Thus, it is firmly believed that managers are quite insensitive to estimates of the probabilities of possible outcomes (March \& Shapira, 1987). Manager decisions are greatly influenced by the way their attention is focused on important performance targets (Veling \& Bijleveld, 2015) and they could make a sharp distinction between taking risks and gambling. Previous scholars who have studied decision-making behavior in risky organizational situations have focused on the direct effects of one or two of these behavioral determinants (Sitkin \& Weingart, 1995). However, this situation has not developed since risk studies have evolved in contexts and perspectives across multiple disciplines.

The concept of risk-taking is different from the perception of risk, and several authors have emphasized the importance of measuring the concept of risk-taking correctly (Bran \& Vaidis, 2020; Sitkin \& Weingart, 1995). Risk-taking is a form of a person's tendency to behave. Michel et al. (2001) define risk-taking as a decision concerning a choice of the degree of uncertainty over the probability of failure or success. Risk for entrepreneurs is not considered as an obstacle to success but becomes a challenge, and entrepreneurs are people who like challenging things to achieve success (Mullins \& Forlani, 2005). Hence, risk-taking is what distinguishes entrepreneurs from others (Brockhaus, 1980), including their readiness to take risks. In the entrepreneurial context, risk-taking is recognized as one of the most 
important characteristics that support entrepreneurial orientation (Covin \& Lumpkin, 2011), and is considered the most important dimension to be explored in-depth (Agustina \& Pradesa, 2020; Kharisma et al., 2020; Lumpkin \& Dess, 1996). Those activities are important to promote sustainable entrepreneurial efforts and initiatives that ensure the renewal of enterprises, which also applies to family firms (Zahra, 2018).

In particular, conceptualizing entrepreneurial risk-taking is quite difficult in a multidimensional construct. In the conceptual area, an expanded definition of entrepreneurial risk-taking focuses on all types of entrepreneurial activity in family firms (Zahra, 2018) and start-ups (Forlani \& Mullins, 2000; Guo \& Jiang, 2020; Mullins \& Forlani, 2005) remains unclear. In its development, the risk-taking framework was also applied and explored in the student analysis unit associated with entrepreneurial intentions (Nathasia \& Rodhiah, 2020; Wijaya et al., 2015). Previous research has also examined gender differences in risk-taking for entrepreneurs (Agustina \& Pradesa, 2020), with the results obtained show that there are no significant differences in risk-taking for both male and female entrepreneurs.

The proposed hypotheses developed in this study are based on the theory of reasoned action (Ajzen, 1991) and the theory of entrepreneurship (Casson, 2005b) in explaining how aspects of risk perception could stimulate risk-taking by entrepreneurs. Risk perception contains cognitive and affective aspects, while risk-taking contains a tendency to behave. It is believed that the two are related to each other, and risk perception as reflected by the dimensions of business insecurity, profit insecurity, and product insecurity can be considered as a determinant of the risk-taking entrepreneur. To test the model presented, we developed three possible hypotheses to explore differences in risk perceptions through the concepts developed by (Weber et al., 2002). This study considers that individual differences in risk can reflect two different processes. First, entrepreneurs may have different perceptions of risk. They may have different perceptions of how risky or beneficial a particular behavior is. Second, entrepreneurs may also differ in their risk-taking behavior. They may differ in the likelihood of engaging in risk-taking behavior. Therefore, risk perception and risk-taking behavior may vary independently.

In a business context, if two or more entrepreneurs, for example, have different perceptions of business insecurity risk, then they may be equally willing (or unwilling) to continue their business (reflecting different risk perceptions on equivalent risk behavior). Or, if two or more entrepreneurs may perceive their business to be equally risky, but one of them is more likely to continue the business and engage in that behavior (reflecting the same risk perception in different risk behaviors). From the example, it can be assumed that risk-taking 
Entrepreneur's perceived risk and risk-taking behavior in the small-sized creative businesses of tourism sector during COVID-19 pandemic by lin Agustina,

Mohd Na'eim Bin Ajis, Hafid Aditya Pradesa

behavior cannot be carried out without reflection on risk perceptions (Davis-Berman \& Berman, 2002).

Concerning today's COVID-19 pandemic situation, it is indeed difficult to predict the possible total loss incurred by the tourism industry. The tourism sector is struggling in this period of crisis. Not only for tourists, both local and foreign, who tend to minimize or eliminate spending on tourism, but at the same time, industry actors must also struggle to keep their businesses alive. Entrepreneurs experience a lot of income declines in all segments, so many of them are trying to find ways to optimize their business operations (Sheth, 2020).

The continuous decline in income has the potential to create insecurity in the business continuity of entrepreneurs, thus encouraging SMEs entrepreneurs to be able to adapt to the current situation and achieve business continuity management (Yuliawati et al., 2021). In addition, entrepreneurs also start thinking about how to reduce risk or minimize the impact of the crisis on their business. Mitigation Business plans need to be carried out by incorporating disaster risk factors where their business practices adopt scenarios about what can be implemented in a crisis (Yuliawati et al., 2021). The ability to respond quickly will be achieved if the entrepreneur has a business continuity management plan, which requires support from stakeholders, such as local governments, the private sector, and financial institutions. Thus, the first hypothesis in this study is formulated as follows:

$\mathrm{H}_{1}$ : Business insecurity has a significant effect on entrepreneurial risk-taking behavior.

Taking a risk exhibits behavior that involves the possibility of obtaining a favorable outcome as well as negative or harmful consequences (Boyer, 2006). The entrepreneurial theory attempts to broaden this view by allowing individuals to differ, not only in risk-taking or risk aversion, but also in their access to information, and therefore exhibit the subjective probabilities on risk assessment.

Perceived risk is also a function of uncertainty and consequences, and one of them includes the uncertainty inherent in the product (Moutinho, 2000). As in other sectors, purchasing products around tourism areas triggers a certain degree of risk-taking (Moutinho, 2000; Roehl \& Fesenmaier, 1992). In tourism studies, like other marketing studies, the concept of risk perception is strongly related to the decisions of entrepreneurs and the behavior of the businesses they operate, in addition to consumer decisions and their travel behavior. This assumption is based on a behavioral perspective, as explained earlier that 
perception of risks are individual and situational and are characterized by type and intensity (Pizam \& Mansfeld, 2006).

The risks to products perceived by entrepreneurs refer to product insecurity, as a result of the cessation of business activities in the tourism area, to reduce the spread of COVID-19 (Ratten, 2020b). The pandemic, as we know, has had a significant impact on the business performance of entrepreneurs in tourism places, especially entrepreneurs of handicraft and fashion products. The risk of physical loss caused by unsold products has the potential to disrupt the product cycle, thereby creating anxiety for entrepreneurs whose product will be damaged and outdated (not following the trend), particularly for fashion products whose turnover tends to be very fast. In this case, the risk of declining product performance gives real fear that it is possible for consumer consumption of the product will require a long period, depending on the existing pandemic situation and government policies. Thus, the second hypothesis in this study is formulated as follows:

$\mathrm{H}_{2}$ : Product insecurity has a significant effect on entrepreneurial risk-taking behavior.

The COVID-19 crisis can be seen as a 'sudden threat', as the crisis develops suddenly and affects not only the entire organization but also the entire economic sector. SMEs entrepreneurs, for example, experience daily loss of income (sales) caused by disrupted supply chains due to the closure of supporting sectors, in addition to labor shortages and a significant decline in cash flow (Fabeil et al., 2020; Shepherd, 2020; Yuliawati et al., 2021). However, the crisis condition due to the COVID-19 pandemic has caused a lot of losses for SMEs businesses. Therefore, entrepreneurs need to think of strategies to manage and plan alternative approaches to not only maintain the continuity of their business but also be able to continue to generate profits and improve their business cash flow.

Risk of profit known as profit insecurity means the entrepreneurs' perception who likely have the risk of losing profits from their business. The perception of entrepreneurs can potentially be right or wrong. When their optimism is warranted, then their investment will be profitable, otherwise, they will bear the loss. Entrepreneurs with good judgment are most likely to succeed, while entrepreneurs with poor judgment are more likely to fail. Furthermore, successful entrepreneurs are usually sustainable because they generate profits, on the other hand, unsuccessful entrepreneurs are usually unsustainable which can ultimately damage business performance and consume all available funds, thus threatening the existence of entrepreneurs and their business continuity. Crisis experiences are known to have led entrepreneurs to act more rationally and be involved in planning when making decisions, 
thereby achieving 'good growth' and earning them a net profit (Dollar \& Kray, 2001). Thus, the third hypothesis in this study is formulated as follows:

$\mathrm{H}_{3}$ : Profit insecurity has a significant effect on entrepreneurial risk-taking behavior.

\section{Methods}

Table 1. Research Instruments

\begin{tabular}{|c|c|c|}
\hline Constructs & Code & Item \\
\hline \multirow{5}{*}{$\begin{array}{l}\text { Business } \\
\text { Insecurity } \\
\text { (BISC) }\end{array}$} & BISC1 & COVID-19 pandemic makes business hard to forecast. \\
\hline & BISC2 & COVID-19 pandemic makes business hard to control. \\
\hline & BISC3 & The line of business looks less conducive. \\
\hline & BISC4 & $\begin{array}{l}\text { COVID-19 pandemic caused a potential decline of business } \\
\text { targets. }\end{array}$ \\
\hline & BISC5 & $\begin{array}{l}\text { COVID-19 pandemic increases the possibility of closing the } \\
\text { business and switching into another one. }\end{array}$ \\
\hline \multirow{3}{*}{$\begin{array}{l}\text { Product } \\
\text { Insecurity } \\
\text { (PdISC) }\end{array}$} & PdISC1 & $\begin{array}{l}\text { COVID- } 19 \text { pandemic creates the potential of a massive reduction } \\
\text { in purchased products. }\end{array}$ \\
\hline & PdISC2 & $\begin{array}{l}\text { There are many damages or expired products that could not be } \\
\text { sold amid the pandemic. }\end{array}$ \\
\hline & PdISC3 & COVID-19 pandemic decreases the quality of the product. \\
\hline \multirow{3}{*}{$\begin{array}{l}\text { Profit } \\
\text { Insecurity } \\
\text { (PrISC) }\end{array}$} & PrISC1 & $\begin{array}{l}\text { Business experiences a huge potential loss due to the COVID-19 } \\
\text { pandemic. }\end{array}$ \\
\hline & PrISC2 & COVID-19 pandemic increases operating costs of the business \\
\hline & PrISC3 & $\begin{array}{l}\text { Businesses cannot meet the profit targets due to the COVID-19 } \\
\text { pandemic. }\end{array}$ \\
\hline \multirow{6}{*}{$\begin{array}{l}\text { Entrepreneurial } \\
\text { Risk-Taking } \\
\text { Behavior } \\
\text { (RTB) }\end{array}$} & RTB1 & $\begin{array}{l}\text { The term "risk-taker" is considered a positive attribute for people } \\
\text { in our business. }\end{array}$ \\
\hline & RTB2 & $\begin{array}{l}\text { People in our business are encouraged to take calculated risks of } \\
\text { new ideas. }\end{array}$ \\
\hline & RTB3 & $\begin{array}{l}\text { Our business emphasizes both exploration and experimentation } \\
\text { for opportunities. }\end{array}$ \\
\hline & RTB4 & Our business has a strong preference for high-risk projects. \\
\hline & RTB5 & $\begin{array}{l}\text { I believe that wide-ranging acts are necessary to achieve a firm's } \\
\text { objectives when situations involving uncertainty }\end{array}$ \\
\hline & RTB6 & $\begin{array}{l}\text { I constitutively adopt a bold strategy and aggressive posture to } \\
\text { maximize the probability of exploiting potential opportunities. }\end{array}$ \\
\hline
\end{tabular}


Figure 1. Research Framework

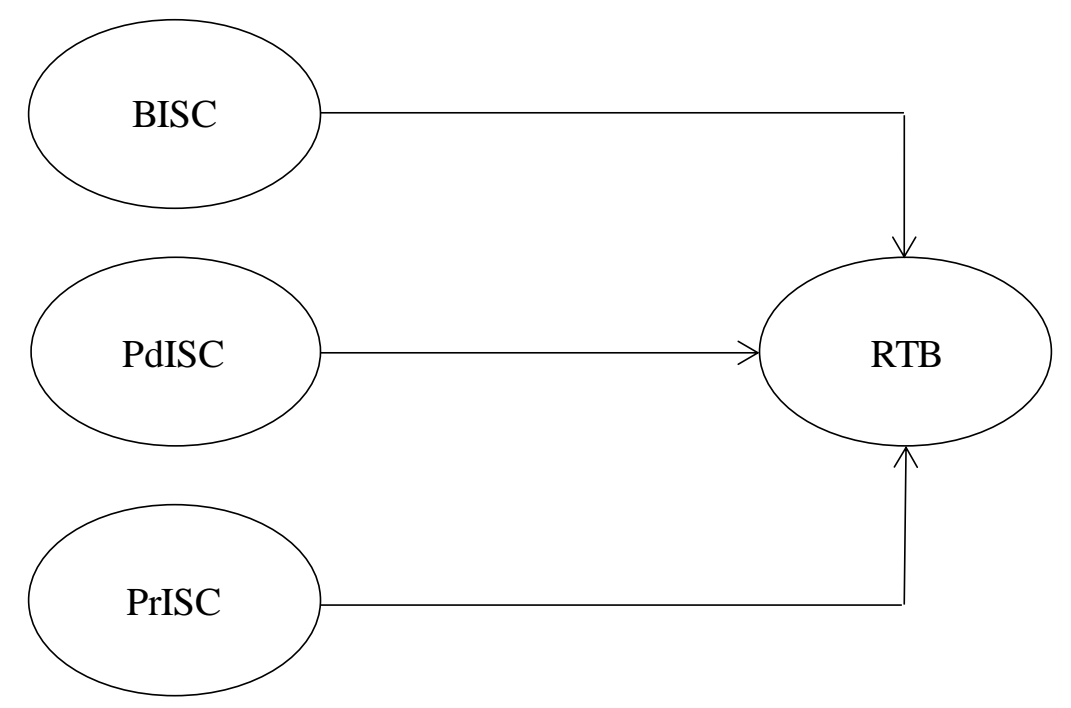

The deductive paradigm with a quantitative approach was employed in the study to answer the objective of the study in which whether there are significant influences between risk perceptions (business insecurity, product insecurity, profit insecurity) on entrepreneurial risk-taking behavior during a crisis like the COVID-19. The study used purposive sampling as a sampling technique with a focus on entrepreneurs from two popular tourism cities in Indonesia, which are Malang (East Java) and Denpasar (Bali). The focuses of the study in exploring entrepreneurial risk-taking behavior in the tourism sector are mainly because the tourism and leisure business has been affected the most by COVID-19, and it is one of the most impacted global industries (Abbas et al., 2021). Moreover, data were collected by distributing the Likert-scale online questionnaires to potential selected respondents. A total of 333 respondents participated in the survey with only 177 of them that are classified and completed all the survey assignments. For the operationalization of concepts on research instruments, several previous research instruments that have been tested and valid were adopted to be the basis for developing and reconstructing statement items in research questionnaires. Table 1 and Figure 1 show the detailed research framework and instruments. Finally, this study conducted Partial Least Square to test the significances of inner and outer models. The results of the analysis will show not only the value of the relationship between variables but also the factor weight value of each indicator on the research variables.

Table 3 presents factor loadings and mean value for each indicator among constructs (risk perception of business insecurity, profit insecurity, product insecurity, and risk-taking behavior) that demonstrate a good fit of constructs validity. Based on loading factor value, risk perception of business insecurity is most reflected by the line of business looks less 
conducive. While risk perception of profit insecurity tends to be reflected by the huge potential for loss during a pandemic, risk perception of product insecurity is most reflected by potential loss quality of the product. Lastly, risk-taking behavior is most reflected by constitutively adopting a bold strategy and aggressive posture to maximize the probability of exploiting potential opportunities. Furthermore, Table 3 shows the result of internal consistency reliability and content validity to assess the reliability and validity of constructs that are observed in the study. The generalized measure of risk-taking is highest compared with the risk perception aspect (business insecurity, profit insecurity, and product insecurity). Table 3 also shows that the relationship between constructs is considered fair, ranging from $0.391-0.671$. While coefficient alpha is italicized in parentheses as seen in Table 3, it operationalizes the true-score model by providing multiple measures of the same theoretical concept, and reliability score in this study estimates ranged from 0.640 to 0.801 .

Table 2. Loading Factors

\begin{tabular}{lcc}
\hline Indices & Loading Statistics & Mean Values \\
\hline BISC1 & 0.710 & 9.941 \\
BISC2 & 0.714 & 10.221 \\
BISC3 & 0.730 & 12.822 \\
BISC4 & 0.638 & 6.080 \\
BISC5 & 0.710 & 9.941 \\
PdISC1 & 0.746 & 9.969 \\
PdISC2 & 0.792 & 9.472 \\
PdISC3 & 0.813 & 13.440 \\
PrISC1 & 0.867 & 19.607 \\
PrISC2 & 0.679 & 6.162 \\
PrISC3 & 0.732 & 8.569 \\
RTB1 & 0.721 & 9.918 \\
RTB2 & 0.578 & 4.670 \\
RTB3 & 0.700 & 9.568 \\
RTB4 & 0.745 & 12.538 \\
RTB5 & 0.741 & 10.037 \\
RTB6 & 0.762 & 15.715 \\
\hline
\end{tabular}


Table 3. Constructs Validity and Reliability

\begin{tabular}{lcccc}
\hline Constructs & \multicolumn{3}{c}{ The Values of $\boldsymbol{\alpha}$ (Sig.) } \\
\hline BISC & $(.719)$ & & & \\
PrISC & $0.633^{* *}$ & $(.640)$ & & \\
PdISC & $0.391^{*}$ & $0.392^{* *}$ & $(.686)$ & \\
RTB & $0.671^{* *}$ & $0.516^{* *}$ & $0.558^{* *}$ & $(.801)$ \\
Mean & 3.903 & 3.919 & 3.938 & 4.030 \\
Standard Deviation & 3.358 & 2.873 & 1.961 & 1.707 \\
\hline
\end{tabular}

Notes: **p: 0.010; *p: 0.050

\section{Result and Discussion}

Table 4. Hypotheses Test Result

\begin{tabular}{lcccc}
\hline Relationship & $\begin{array}{c}\text { Loading } \\
\text { Statistics }\end{array}$ & t-Statistics & t-Table & Decision \\
\hline BISC -> RTB & 0.465 & 4.132 & 1.973 & $\mathrm{H}_{1}$ Accepted \\
PdISC -> RTB & 0.156 & 1.466 & 1.973 & $\mathrm{H}_{2}$ Rejected \\
PrISC -> RTB & 0.274 & 2.989 & 1.973 & $\mathrm{H}_{3}$ Accepted \\
\hline
\end{tabular}

The majority of respondents in this study were male (52.5\%) with handicrafts-focused business (58\%) and Denpasar as the majority of respondents domicile (53\%). Therefore, based on the results of the significances test in table 4 , it can be concluded that there is a significant effect between business insecurity and entrepreneurial risk-taking behavior among respondents of the study as the result of t-statistics of the proposed hypothesis was higher than t-tables $(4.132>1.973)$. Besides, Table 4 also shows that there is a significant effect between product insecurity and entrepreneurial risk-taking behavior as the result of t-statistics of the proposed hypothesis was higher than t-tables $(2.989>1.973)$. However, the significant effect of profit security on entrepreneurial risk-taking behavior was failed to prove since the result of t-statistics of the proposed hypothesis was lower than t-tables $(1.466<1.973)$. It means that the higher the level of business and product insecurity perceptions (as long as it can generate profitability and ensure business sustainability), the higher the level of risktaking of entrepreneurs.

Standard parameter estimates for the model are also presented in the Appendix. It displays the result of each path of the model proposed in this study. From the Appendix, the path coefficient shown about the R-square score is 0.540 . These results indicate that the 
Entrepreneur's perceived risk and risk-taking behavior in the small-sized creative businesses of tourism sector during COVID-19 pandemic by lin Agustina, Mohd Na'eim Bin Ajis, Hafid Aditya Pradesa

explanatory variance of risk-taking in terms of risk perception is $54 \%$, while the remaining $46 \%$ are other factors outside the three aspects of risk perception. It is important to consider the greatest effect among risk perception dimensions on risk-taking among entrepreneurs. The findings suggest that business insecurity - such as the potential for reducing business targets, temporarily closing businesses, and switching to other businesses making business more difficult to control and predict - can have the greatest effect on entrepreneurs' propensity to take risks. The findings show that risk perception as a form of feeling, influence, and cognition (Arini, 2016; Loewenstein et al., 2001; Slovic \& Peters, 2006) can be considered and customized as a multidimensional construct (Holtgrave \& Weber, 1993; Wolff et al., 2019). Although one of these dimensions was found to have no significant effect on risk-taking, this study provides a new understanding as well as empirical evidence on exploring the concept of risk perception. Two of the risk perception constructs have a significant effect on risk-taking behavior. Regarding the connection between risk perception and risk-taking behavior, findings can confirm previous important findings (Forlani \& Mullins, 2000; Sitkin \& Weingart, 1995).

The results reveal interesting information that the entrepreneur's risk perception is more about the fear of losing customers and the products they produce. A different phenomenon for business insecurity and product insecurity with comparable effects on risk-taking is the impact bias. To date, this study has developed aspects of risk perception among entrepreneurs and entrepreneurial risk-taking in a pandemic context. With the increasing recognition of findings, considering these variables as a series of activities (or even processes) would have better implications that give substance and meaning to the entrepreneurial capabilities of business by ascertaining their regenerative qualities and providing direction to these activities.

The crisis caused by the COVID-19 outbreak has been running for one and a half years. It not only makes healthy people sick, but the pandemic also makes a good business chaotic. Entrepreneurial business models and approaches merely affected by the pandemic will have an impact on how entrepreneurship is perceived as a future job choice. While most startups may view shifting business focus as an opportunity or a short-term solution mostly for entrepreneurs, it still needs a fundamental survival and coping strategy and building growth opportunity for the nation's economy and industry. As part of that, the handicraft and fashion sector managed by an entrepreneur in tourism areas must be considered and empowered properly in the current pandemic situation. While entrepreneurs must dare to take risks in 
every business they do, they also must be able to manage all issues and then receive financial and non-financial profits and losses. It is commonly recognized that taking risks is one of the keys to starting a business. But this research shows that taking risks is the result of efforts to maintain business sustainability when entrepreneurs feel that the risk to the continuity of their business and the potential for losing their products or customers is increasing, this will encourage them to take risks. However, this study only focuses on the determinants of risktaking, with regards to the perspective from an entrepreneurial lens in perceiving risk in business during the pandemic. This research opens a potency for further research on how to encourage entrepreneurs in taking risks is also carried out in a measured and thorough manner.

\section{Conclusion and Suggestion}

The result of the study revealed that among the three aspects of risk perception assessed by entrepreneurs, there are only two aspects that were proven to have an influence on the degree of entrepreneurial risk-taking (especially in the current pandemic situation) namely business insecurity and product insecurity. While entrepreneurs' perceived risk on business and product aspects was the most significant aspect that could affect their risk-taking behavior, entrepreneurs' perceived risk on profit aspects has an insignificant influence on their risk-taking behavior. It implies that the higher the level of business and product insecurity perceptions (as long as it can generate profitability and ensure business sustainability), the higher the level of risk-taking of entrepreneurs. Risk-taking behavior is most reflected by constitutively adopting a bold strategy and aggressive posture to maximize the probability of exploiting potential opportunities in the study. The result of the current study gives widely understanding of entrepreneurs' risk perception and risk-taking behavior in the tourism sector within varying business contexts. Future research could examine for more detailed and precise descriptions of how risk perception is built and measured. The usages of more precise methodological and standardization in the definition and assessment of risk perception may increase the accumulation of knowledge and even allow for the discovery of new cognitive biases like different risk aspect of a business. However, this study also has several limitations. First, the scope of the subject was limited which may not represent the situations of overall countries. Second, large multi-subject in risk analysis and studies require researchers to assess risk about their organization (i.e. business, education) as well as the study in general as this can influence how they perceive risk. Third, one of the drawbacks of using a questionnaire is the fact that it lacks interaction and response from 
Entrepreneur's perceived risk and risk-taking behavior in the small-sized creative businesses of tourism sector during COVID-19 pandemic by lin Agustina,

Mohd Na'eim Bin Ajis, Hafid Aditya Pradesa

entrepreneurs regarding their answers. Therefore, there is the possibility that different measures of risk perception or risk-taking may lead to different findings.

\section{References}

Abbas, J., Mubeen, R., Iorember, P. T., Raza, S., \& Mamirkulova, G. (2021). Exploring the impact of COVID-19 on tourism: transformational potential and implications for a sustainable recovery of the travel and leisure industry. Current Research in Behavioral Sciences, 2, 100033. https://doi.org/10.1016/j.crbeha.2021.100033

Agustin, I. N. (2021). How does the impact of the COVID-19 pandemic on Indonesia's Islamic stock returns? JEMA: Jurnal Ilmiah Bidang Akuntansi Dan Manajemen, 18(1), 21-35. https://doi.org/10.31106/jema.v18i1.9235

Agustina, I., \& Pradesa, H. A. (2020). Gender Differences in Risk Taking Among Entrepreneurs : Case on Small Medium Enterprise in Malang. Warmadewa Management and Business Journal (WMBJ), 2(2), 63-72. https://doi.org/10.22225/wmbj.2.2.1939.6372

Ajzen, I. (1991). The Theory of Planned Behavior. Organizational Behavior and Human Decision Processes, 50, 179-211. https://doi.org/10.1080/10410236.2018.1493416

Arini, A. T. (2016). Persepsi Risiko di Indonesia: Tinjauan Kualitatif Sistematik. Buletin Psikologi, 20(1-2), 66-81. https://doi.org/10.22146/bpsi.11949

Bartz, W., \& Winkler, A. (2016). Flexible or fragile? the growth performance of small and young businesses during the global financial crisis - evidence from Germany. Journal of Business Venturing, 31(2), 196-215.

Bohm, J., \& Harris, D. (2010). Risk Perception and Risk-Taking Behavior of Construction Site Dumper Drivers. International Journal of Occupational Safety and Ergonomics, 16(1), 55-67. https://doi.org/10.1080/10803548.2010.11076829

Boholm, A. (1998). Comparative studies of risk perception: a review of twenty years of research. Journal of Risk Research, 1(2), 135-163.

Boyer, T. W. (2006). The Development of Risk-Taking: A Multi-Perspective Review. Development Review, 26, 291-345.

Bran, A., \& Vaidis, D. C. (2020). Assessing risk-taking: what to measure and how to measure it. Journal of Risk Research, 23(4), 490-503. https://doi.org/10.1080/13669877.2019.1591489

Brockhaus, R. H. (1980). Risk Taking Propensity of Entrepreneurs. Academy of Management 
Journal, 23(3), 509-520. https://doi.org/10.5465/255515

Casson, M. (2005a). Entrepreneurship and the theory of the firm. Journal of Economic Behavior and Organization, 58(2), 327-348. https://doi.org/10.1016/j.jebo.2004.05.007

Casson, M. (2005b). Entrepreneurship and the theory of the firm. Journal of Economic Behavior \& Organization, 58, 327-348. https://doi.org/10.1016/j.jebo.2004.05.007 Cheung, H. Y., Wu, J., \& Tao, J. (2013). Risk Perception and Risk-Taking Attitude: A Comparison Between Hong Kong and Mainland Chinese Undergraduate Students. AsiaPacific Education Researcher, 22(4), 497-506. https://doi.org/10.1007/s40299-0120048-7

Chew, E. Y. T., \& Jahari, S. A. (2014). Destination image as a mediator between perceived risks and revisit intention: A case of post-disaster Japan. Tourism Management, 40, 382393. https://doi.org/10.1016/j.tourman.2013.07.008

Christman, S. D., Jasper, J. D., Sontam, V., \& Cooil, B. (2007). Individual differences in risk perception versus risk taking: Handedness and interhemispheric interaction. Brain and Cognition, 63(1), 51-58. https://doi.org/10.1016/j.bandc.2006.08.001

Covin, J. G., \& Lumpkin, G. T. (2011). Entrepreneurial Orientation Theory and Research : Reflections on a Needed Construct. Entrepreneurship Theory and Practice, September 2011, 855-872. https://doi.org/10.1111/j.1540-6520.2011.00482.x

Davidson, M. C. G., \& Wang, Y. (2011). Sustainable labor practices? hotel human resource managers views on turnover and skill shortages. Journal of Human Resources in Hospitality and Tourism, 10(3), 235-253. https://doi.org/10.1080/15332845.2011.555731

Davis-Berman, J., \& Berman, D. (2002). Risk and anxiety in adventure programming. The Journal of Experiential Education, 25, 305-310.

Dionne, G., Fluet, C., \& Desjardins, D. (2007). Predicted risk perception and risk-taking behavior: The case of impaired driving. Journal of Risk Uncertainty, 35, 237-264.

Dislich, F. X. R., Zinkernagel, A., Ortner, T. M., \& Schmitt, M. (2010). Convergence of direct, indirect, and objective risk-taking measures in gambling. Journal of Psychology, 218(1), 20-27.

Dollar, D., \& Kray, A. (2001). Growth is good for the poor (No. 2587; World Bank Policy Research Department Working Paper).

Dryhurst, S., Schneider, C. R., Kerr, J., Freeman, A. L. J., Recchia, G., van der Bles, A. M., Spiegelhalter, D., \& van der Linden, S. (2020). Risk perceptions of COVID-19 around the world. Journal of Risk Research, 23(7-8), 994-1006. 
Entrepreneur's perceived risk and risk-taking behavior in the small-sized creative businesses of tourism sector during COVID-19 pandemic by lin Agustina,

Mohd Na'eim Bin Ajis, Hafid Aditya Pradesa

https://doi.org/10.1080/13669877.2020.1758193

Fabeil, N. F., Pazim, K. H., \& Langgat, J. (2020). The Impact of Covid-19 Pandemic Crisis on Micro-Enterprises: Entrepreneurs' Perspective on Business Continuity and Recovery Strategy. Journal of Economics and Business, 3(2), 837-844.

https://doi.org/10.31014/aior.1992.03.02.241

Floyd, M. F., Gibson, H., Pennington-Gray, L., \& Thapa, B. (2004). The effect of risk perceptions on intentions to travel in the aftermath of September 11, 2001. Journal of Travel \& Tourism Marketing, 15(2-3), 19-38. https://doi.org/10.1300/ J073v15n02_02

Forlani, D., \& Mullins, J. W. (2000). Perceived risks and choices in entrepreneurs' new venture decisions. Journal of Business Venturing, 15(4), 305-322. https://doi.org/10.1016/S0883-9026(98)00017-2

Gössling, S., Scott, D., \& Hall, C. M. (2020). Pandemics, tourism and global change: a rapid assessment of COVID-19. Journal of Sustainable Tourism, 29(1), 1-20. https://doi.org/10.1080/09669582.2020.1758708

Guo, Z., \& Jiang, W. (2020). Risk-taking for entrepreneurial new entry: risk-taking dimensions and contingencies. International Entrepreneurship and Management Journal, 16(2), 739-781. https://doi.org/10.1007/s11365-019-00567-8

Holtgrave, D. R., \& Weber, E. U. (1993). Dimensions of Risk Perception for Financial and Health Risks. Risk Analysis, 13(5), 553-558. https://doi.org/10.1111/j.15396924.1993.tb00014.x

Huynh, T. L. D. (2020). Data for understanding the risk perception of COVID-19 from Vietnamese sample. Data in Brief, 30, 105530. https://doi.org/10.1016/j.dib.2020.105530

Joo, D., Xu, W., Lee, J., Lee, C.-K., \& Woosnam, K. M. (2021). Residents’ perceived risk, emotional solidarity, and support for tourism amidst the COVID-19 pandemic. Journal of Destination Marketing \& Management, 19, 1-11. https://doi.org/10.1016/j.jdmm.2021.100553

Jungermann, H., \& Slovic, P. (1993). Characteristics of Individual Risk Perception. In Bayerische-Rueck (Ed.), Risk - A Construct (pp. 85-102). Knesebeck.

Karim, W., Haque, A., Anis, Z., \& Ulfy, M. A. (2020). The Movement Control Order (MCO) for COVID-19 Crisis and its Impact on Tourism and Hospitality Sector in Malaysia. International Tourism and Hospitality Journal, 3(2), 1-7. https://doi.org/10.37227/ithj2020-02-09 
Kasperson, R. E., Renn, O., Slovic, P., Brown, H. S., Emel, J., Goble, R., Kasperson, J. X., \& Ratick, S. (1988). The Social Implications of Risk: A Conceptual Framework. Risk Analysis, 8(2), 177-187.

Kato, M., \& Charoenrat, T. (2018). Business continuity management of small and medium sized enterprises: Evidence from Thailand. International Journal of Disaster Risk Reduction, 27, 577-587. https://doi.org/10.1016/J.IJDRR.2017.10.002

Kharisma, P. P., Irawanto, D. W., \& Rofiq, A. (2020). Entrepreneurial Orientation and Its Effect Toward SMEs Performance Through Strategic Flexibility on Fashion Industry in Malang. JBTI : Jurnal Bisnis : Teori Dan Implementasi, 11(2), 81-97.

Kongoley, P. S. (2015). The Impact of Ebola on the Tourism and Hospitality Industry in Sierra Leone. International Journal of Scientific and Research Publications, 5(12), 542550.

Kummeneje, A.-M., \& Rundmo, T. (2020). Attitudes, risk perception and risk-taking behaviour among regular cyclists in Norway. Transportation Research, Part F 69, 135150. https://doi.org/10.1016/j.trf.2020.01.007

Lapointe, D. (2020). Reconnecting tourism after COVID-19: the paradox of alterity in tourism areas. Tourism Geographies, 22(3), 633-638. https://doi.org/10.1080/14616688.2020.1762115

Laurence Kern, A., Geneau, S., Laforest, A. D., Tremblay, B., Goulet, C., Lepage, S., \& Barnett, T. A. (2014). Risk perception and risk-taking among skateboarders. Safety Science, 62, 370-375. https://doi.org/10.1016/j.ssci.2013.08.009

Le Breton, D. (2018). Ambivalence in the World Risk Society. Theory, Culture and Society, 35(7-8), 141-156. https://doi.org/10.1177/0263276418810416

Le, D., \& Phi, G. (2021). Strategic responses of the hotel sector to COVID-19: Toward a refined pandemic crisis management framework. International Journal of Hospitality Management, 94, 1-5. https://doi.org/10.1016/j.ijhm.2020.102808

Liñán, F., \& Jaén, I. (2020). The Covid-19 pandemic and entrepreneurship: some reflections. International Journal of Emerging Markets, 1-12. https://doi.org/10.1108/IJOEM-052020-0491

Loewenstein, G. F., Hsee, C. K., Weber, E. U., \& Welch, N. (2001). Risk as Feelings. Psychological Bulletin, 127(2), 267-286. https://doi.org/10.1037/0033-2909.127.2.267 Lumpkin, G. T., \& Dess, G. G. (1996). Clarifying the Entrepreneurial Orientation Construct and Linking It to Performance. The Academy of Management Review, 21(1), 135-172. March, J. G., \& Shapira, Z. (1987). Managerial Perspectives on Risk and Risk Taking. 
Entrepreneur's perceived risk and risk-taking behavior in the small-sized creative businesses of tourism sector during COVID-19 pandemic by lin Agustina, Mohd Na'eim Bin Ajis, Hafid Aditya Pradesa

Management Science, 33(1), 1404-1418. https://doi.org/10.1287/mnsc.33.11.1404

Michel, G., Le Heuzey, M. F., Purper-Ouakil, D., \& Mouren-Siméoni, M. C. (2001).

Recherche de sensations et conduites à risque chez l'adolescent - Risk-taking behaviors and sensation seeking in adolescence. Annales Médicopsychologiques, Revue Psychiatrique, 159(10), 708-716.

Mishra, S., Lalumiere, M. L., \& Williams, R. J. (2010). Gambling as a form of risk-taking: Individual differences in personality, risk accepting attitudes, and behavioral preferences for risk. Personality and Individuals Differences, 49, 616-621.

Moutinho, L. (2000). Consumer Behavior in Tourism. In L. Moutinho (Ed.), Strategic Management in Tourism. CABI.

Mullins, J. W., \& Forlani, D. (2005). Missing the boat or sinking the boat: A study of new venture decision making. Journal of Business Venturing, 20(1), 47-69. https://doi.org/10.1016/j.jbusvent.2003.08.001

Nathasia, \& Rodhiah. (2020). Pengaruh Inovasi, Kepercayaan Diri Dan Pengambilan Risiko Terhadap Intensi Berwirausaha Pada Mahasiswa Universitas Tarumanagara. Manajerial Dan Kewirausahaan, II(1), 12-21.

Nepal, S. K. (2020). Adventure travel and tourism after COVID-19-business as usual or opportunity to reset? Tourism Geographies, 22(3), 646-650. https://doi.org/10.1080/14616688.2020.1760926

Pizam, A., \& Mansfeld, Y. (2006). Toward a Theory of Tourism Security. In Y. Mansfeld \& A. Pizam (Eds.), Tourism, Security \& Safety (pp. 1-27). Elsevier ButterworthHeinemann.

Ratten, V. (2020a). Coronavirus (covid-19) and entrepreneurship: changing life and work landscape. Journal of Small Business and Entrepreneurship, 32(5), 503-516. https://doi.org/10.1080/08276331.2020.1790167

Ratten, V. (2020b). Coronavirus (Covid-19) and entrepreneurship: cultural, lifestyle and societal changes. Journal of Entrepreneurship in Emerging Economies. https://doi.org/10.1108/JEEE-06-2020-0163

Reniers, R. L. E. P., Murphy, L., Lin, A., Bartolomé, S. P., \& Wood, S. J. (2016). Risk Perception and Risk-Taking Behaviour during Adolescence: The Influence of Personality and Gender. Plos One, 11(4), e0153842. https://doi.org/10.1371/journal.pone.0153842

Renn, O., Siovic, P., Burns, W. J., Kasperson, J. X., \& Kasperson, R. E. (1992). Social 
amplification theory: Theoretical foundations and empirical applications. Journal of Social Issues, 48(4), 127-160.

Riddel, M. (2009). Risk Perception, Ambiguity, and Nuclear-Waste Transport. Southern Economic Journal, 75(3), 781-797.

Roehl, W. S., \& Fesenmaier, D. R. (1992). Risk Perception and Pleasure Travel: An Explanatory Analysis. Journal of Travel Research, 30(4), 17-26.

Shepherd, D. A. (2020). COVID 19 and Entrepreneurship: Time to Pivot? Journal of Management Studies, 57(8), 1750-1753. https://doi.org/10.1111/joms.12633

Sheth, J. (2020). Impact of Covid-19 on consumer behaviour: Will the old habits return or die? Journal of Business Research, 117, 280-283.

Sigala, M. (2020). Tourism and COVID-19: Impacts and implications for advancing and resetting industry and research. Journal of Business Research, 117, 312-321. https://doi.org/10.1016/j.jbusres.2020.06.015

Sitkin, S. B., \& Weingart, L. R. (1995). Determinants of Risky Decision-Making Behavior. Academy of Management Journal, 38(6), 1573-1592.

Slovic, P. (1987). Perception of Risk. Science, 236(4799), 280-285.

Slovic, P. (1992). Perception of Risk: Reflections on the Psychometric Paradigm. Social Theories of Risk, 117-152.

Slovic, P., Finucane, M. L., Peters, E., \& MacGregor, D. G. (2004). Risk as Analysis and Risk as Feelings: Some Thoughts about Affect, Reason, Risk, and Rationality. Risk Analysis, 24(2), 311-322. https://doi.org/10.1111/j.0272-4332.2004.00433.x

Slovic, P., \& Peters, E. (2006). Risk perception and affect. Current Directions in Psychological Science, 15(6), 322-325. https://doi.org/10.1111/j.14678721.2006.00461.x

Slovic, P., Peters, E., Finucane, M. L., \& MacGregor, D. G. (2005). Affect, risk, and decision making. Health Psychology, 24(4 SUPPL.), 35-40. https://doi.org/10.1037/02786133.24.4.S35

Soane, E., Dewberrry, C., \& Narendran, S. (2010). The role of perceived costs and perceived benefits in the relationship between personality and risk-related choices. Journal of Risk Research, 13(3), 303-318.

Tahar, A., Sofyani, H., \& Kunimasari, D. P. (2021). IT governance and IT application orchestration capability role on organization performance during the COVID-19 pandemic: An intervening of business-IT alignment. JEMA: Jurnal Ilmiah Bidang Akuntansi Dan Manajemen, 18(1), 1-20. https://doi.org/10.31106/jema.v18i1.9311 
Entrepreneur's perceived risk and risk-taking behavior in the small-sized creative businesses of tourism sector during COVID-19 pandemic by lin Agustina, Mohd Na'eim Bin Ajis, Hafid Aditya Pradesa

Veling, H., \& Bijleveld, E. (2015). When performance and risk taking are related: Working for rewards is related to risk taking when the value of rewards is presented briefly. Brain and Cognition, 101, 44-50. https://doi.org/10.1016/j.bandc.2015.11.001

Weber, E. U., Blais, A.-R., \& Betz, N. E. (2002). A Domain-specific Risk-attitude Scale: Measuring Risk Perceptions and Risk Behaviors. Journal of Behavioral Decision Making, 15(August), 263-290.

Wijaya, T., Nurhadi, N., \& Kuncoro, A. M. (2015). Intensi berwirausaha mahasiswa: Perspektif pengambilan risiko. Jurnal Siasat Bisnis, 19(2), 109-123. https://doi.org/10.20885/jsb.vol19.iss2.art2

Wolff, K., Larsen, S., \& Øgaard, T. (2019). How to define and measure risk perceptions. Annals of Tourism Research, 79(July). https://doi.org/10.1016/j.annals.2019.102759

Y1ldırım, M., \& Güler, A. (2020). Factor analysis of the COVID-19 Perceived Risk Scale: A preliminary study. Death Studies, 1-8. https://doi.org/10.1080/07481187.2020.1784311

Yuliawati, A. K., Rofaida, R., Gautama, B. P., \& Aryanti, A. N. (2021). Business Continuity of MSMEs in Small Island Facing the Covid-19 Pandemic. GATR Journal of Business and Social Science Review, 9(1), 90-98. https://doi.org/10.35609/gjbssr.2021.9.1(10)

Zahra, S. A. (2018). Entrepreneurial Risk Taking in Family Firms: The Wellspring of the Regenerative Capability. Family Business Review, 31(2), 216-226. https://doi.org/10.1177/0894486518776871

Zhao, Y., \& Xu, H. (2020). Chinese public attention to COVID-19 epidemic: Based on social media. MedRxiv, March 2020. https://doi.org/10.1101/2020.03.18.20038026 
JEMA: Jurnal IImiah Bidang Akuntansi dan Manajemen, 18(2) 2021,187-209

http://dx.doi.org/10.31106/jema.v18i2.12563, ISSN (Online) 2597-4017

\section{Appendix}

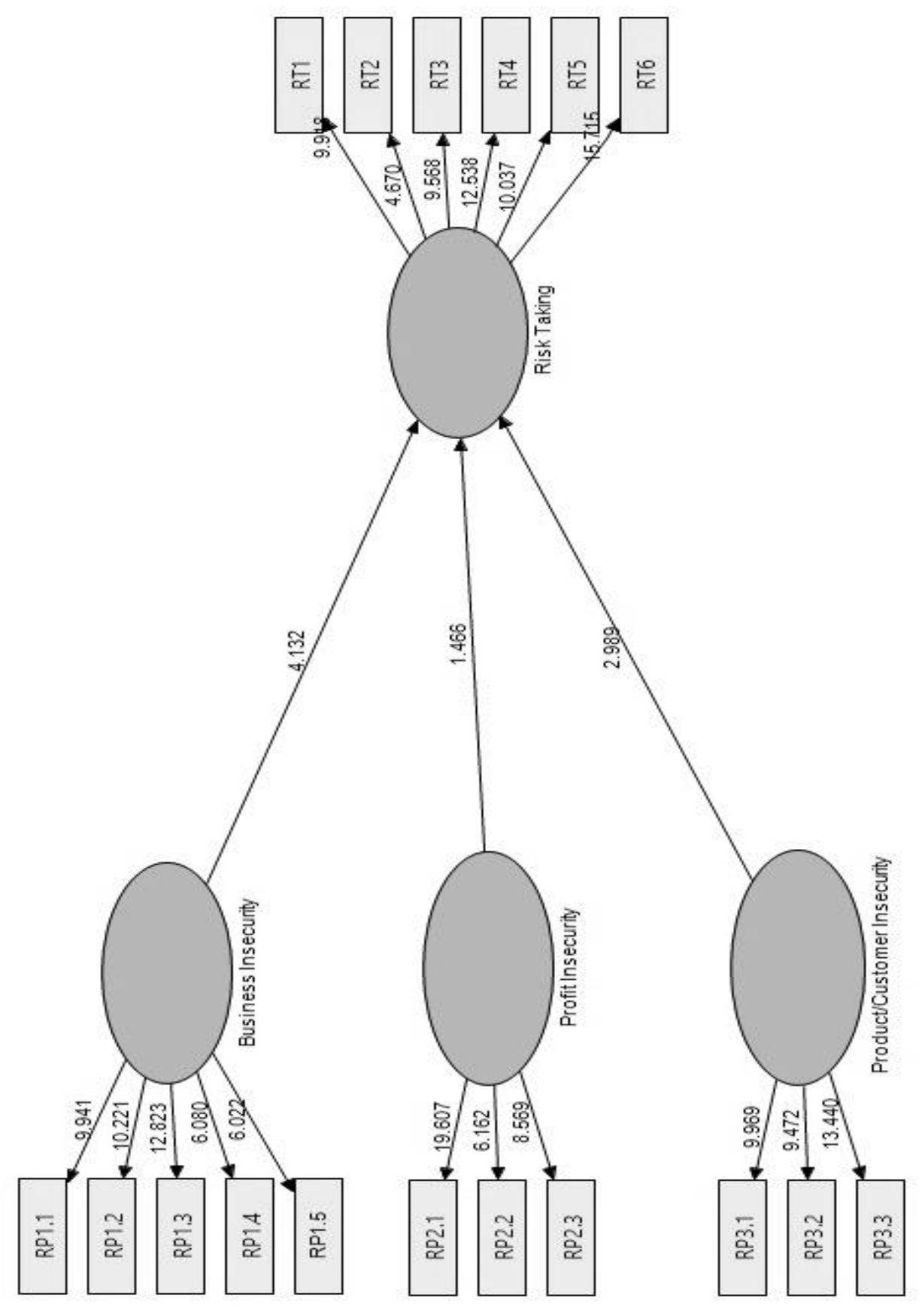

